\title{
The Structure of Riparian Vegetation in Agricultural Landscapes Influences Spider Communities and Aquatic-Terrestrial Linkages
}

\author{
Ellinor Ramberg ${ }^{1,2}$, Francis J. Burdon ${ }^{1}{ }^{(D}$, Jasmina Sargac ${ }^{1}$, Benjamin Kupilas ${ }^{3,4}{ }^{(D)}$, \\ Geta Rîşnoveanu $^{5,6}{ }^{(D}$, Danny C. P. Lau ${ }^{7} \mathbb{D}$, Richard K. Johnson ${ }^{1}$ and Brendan G. McKie ${ }^{1, *(\mathbb{D})}$ \\ 1 Department of Aquatic Sciences and Assessment, Swedish University of Agricultural Sciences, \\ 75007 Uppsala, Sweden; ellinor.karin.ramberg@slu.se (E.R.); francis.burdon@slu.se (F.J.B.); \\ jasmina.sargac@slu.se (J.S.); richard.johnson@slu.se (R.K.J.) \\ 2 Department of Ecology, Swedish University of Agricultural Sciences, 75007 Uppsala, Sweden \\ 3 Norwegian Institute for Water Research (NIVA), 0349 Oslo, Norway; benjamin.kupilas@niva.no \\ 4 Institute of Landscape Ecology, University of Münster, 48149 Münster, Germany \\ 5 Department of Systems Ecology and Sustainability, University of Bucharest, 050095 Bucharest, Romania; \\ geta.risnoveanu@g.unibuc.ro \\ 6 Research Institute of the University of Bucharest, 050663 Bucharest, Romania \\ 7 Department of Ecology and Environmental Science, Umeå University, 90187 Umeå, Sweden; \\ danny.lau@umu.se \\ * Correspondence: brendan.mckie@slu.se
}

Received: 25 August 2020; Accepted: 12 October 2020; Published: 14 October 2020

\begin{abstract}
Riparian habitats are important ecotones connecting aquatic and terrestrial ecosystems, but are often highly degraded by human activities. Riparian buffers might help support impacted riparian communities, and improve trophic connectivity. We sampled spider communities from riparian habitats in an agricultural catchment, and analyzed their polyunsaturated fatty acid (PUFA) content to quantify trophic connectivity. Specific PUFAs are exclusively produced by stream algae, and thus are used to track uptake of aquatic resources by terrestrial consumers. Riparian spiders were collected from 10 site pairs situated along agricultural streams, and from five forest sites ( 25 sites total). Each agricultural site pair comprised an unshaded site with predominantly herbaceous vegetation cover, and a second with a woody riparian buffer. Spider communities differed between site types, with web-building spiders dominating woody buffered sites and free-living spiders associated with more open habitats. PUFA concentrations were greatest overall in free-living spiders, but there was also evidence for increased PUFA uptake by some spider groups when a woody riparian buffer was present. Our results reveal the different roles of open and wooded riparian habitats in supporting terrestrial consumers and aquatic-terrestrial connectivity, and highlight the value of incorporating patches of woody vegetation within riparian networks in highly modified landscapes.
\end{abstract}

Keywords: ecotone; polyunsaturated fatty acids; trophic connectivity; agriculture; spiders; riparian buffer

\section{Introduction}

Streams and their adjacent riparian zones are recognized as important habitats supporting high biodiversity and providing a range of ecosystem services [1-4]. These habitats are closely linked through multiple exchanges of organisms, nutrients and materials, which often act as "resource subsidies" in the recipient habitat [5]. For example, inputs of terrestrial detritus into stream habitats provide an energy source for microbes and detritivores, and the emergence of the adult winged stages of aquatic 
insects provide prey and nutrient subsidies for riparian consumers [6]. Importantly, aquatic insects assimilate not only carbon and nutrients in aquatic habitats but also high quality polyunsaturated fatty acids (PUFAs; e.g., $\omega 3$ fatty acids), which they export to terrestrial food webs as adults [7-9]. PUFAs are essential for several biological functions across a wide range of organisms [7,10-12]. Higher plants and algae, and to some degree fungi, are the main sources of PUFAs for consumers, with several types of especially long-chain (with $\geq 20$ carbon) PUFAs produced almost exclusively in aquatic environments by algae $[7,13,14]$. This aspect makes PUFAs suitable biomarkers for tracking the uptake of aquatic subsidies into terrestrial food webs [15]. Consequently, PUFAs may be particularly useful for studying trophic connectivity in stream-riparian networks where the ecosystem boundary is relatively well-defined, and the spatial scale for conducting research is tractable [16].

Riparian habitats are often highly degraded in agricultural landscapes, reflecting the legacy of long-term declines in riparian woodlands, and more recent pressures associated with agricultural intensification [17]. Losses of riparian integrity are associated with increased insolation of stream and soil habitats, bank erosion and increased sediment loads, and with modified vegetation composition, fragmentation of riparian forest habitats, and declines in biodiversity [18-20]. Together, these changes might affect the quantity and quality of resource flows from aquatic to terrestrial habitats by: (i) altering in stream productivity of aquatic resources (e.g., algae producing PUFAs) and biomass of emerging adult aquatic insects; (ii) disrupting the transfer of aquatic subsidies by affecting survival and dispersal distances of adult aquatic insects; and (iii) reducing the uptake of aquatic subsidies into terrestrial food webs, due to impacts on the biodiversity and feeding activities of key terrestrial consumer groups, including terrestrial invertebrates [21-25].

Environmental variation can affect aquatic PUFA production both indirectly, e.g., by altering the community composition of algae [26-29] and directly, by modifying PUFA production by particular algal taxa [23]. For example, diatoms thrive in cool, moderately shaded, flowing waters [28,30,31] and are major producers of eicosapentaenoic acid (EPA), an omega-3 PUFA [13,32,33]. The levels of EPA synthesised by diatoms are in turn regulated by light, temperature and nutrient levels $[23,34]$. Specifically, long-chain PUFA content in diatoms increases at low irradiances and temperatures, whereas high nutrient levels can have a negative effect of long-chain PUFA production even when overall algal production is stimulated [23,34]. Thus, anthropogenic activities that reduce riparian wooded vegetation (shading) and increase eutrophication and sediment loads can alter both algal community composition and potential PUFA production in aquatic systems.

Riparian predators, such as spiders, that use aquatic subsidies are sensitive to environmental changes and are thus ideal organisms to study the influence of different riparian habitat types on aquatic-terrestrial linkages [6,22,35]. Different spider families vary in their trophic reliance on aquatic subsidies, reflecting their association with aquatic habitats and specialisation on aquatic prey. Web-building Tetragnathidae spiders are strongly associated with emergent wetland vegetation, and are often highly reliant on aquatic prey. Results for Linyphiidae and Araneidae are more variable [35-38], though Laeser et al. [22] found that web-building spiders were overall negatively associated with clearance of riparian vegetation, due in part to the loss of habitat structures needed for web-building. Lycosid spiders can also be highly reliant on aquatic subsidies [35,38,39], and although ground hunting spiders are not dependent on woody vegetation to support web-building, they may be impacted by other changes associated with losses of riparian vegetation, including reduced humidity and increased habitat fragmentation.

Improving our understanding of how riparian vegetation affects aquatic-terrestrial communities and the trophic linkages between them will help develop effective riparian management strategies targeting improved ecological status of stream-riparian networks. We conducted a field investigation across multiple sites in an agricultural region of central Sweden, focusing on riparian communities and trophic connectivity in stream-riparian networks. We assessed how spider diversity, abundances, and their PUFA composition vary with riparian properties (e.g., comparing agricultural reaches with and without a forested buffer). We hypothesized that: 
1. Riparian spider community composition differs between buffered, unbuffered and forest sites. This hypothesis reflects an expectation of lower abundances of web-building spiders in particular at unbuffered sites, due to the deficiency of vegetation structures suitable for building webs, with spider diversity and abundance expected to increase overall with increases in riparian forest cover, due to a larger variation in available habitat niches.

2. Consistent with more favorable conditions for algae that produce long-chain PUFAs, higher concentrations of long-chain PUFAs (e.g., EPA) will be found in spiders from forested sites (buffered and forest reference sites) than the unbuffered agricultural sites; and

3. Spider taxonomic groups shown to be highly reliant on aquatic subsidies, such as the Tetragnathidae and Lycosidae, have increased long-chain PUFA content reflecting greater consumption of aquatic-derived prey.

\section{Materials and Methods}

\subsection{Study Sites}

Our study sites were located in the Lake Ekoln basin (part of the Lake Mälaren catchment) of Uppland, Sweden (Figure 1). The region is characterized by a mosaic of land-use types dominated by forest and agriculture, and includes the city of Uppsala (pop. $\approx 168,000$ ) [40]. The region has a warm humid continental climate (Köppen Climate Classification Dfb) with mean annual precipitation of $544 \mathrm{~mm}$ and temperature of $5.6^{\circ} \mathrm{C}$. However, during 2018 (the year of the study), the summer months were both warmer and dryer than average [41].

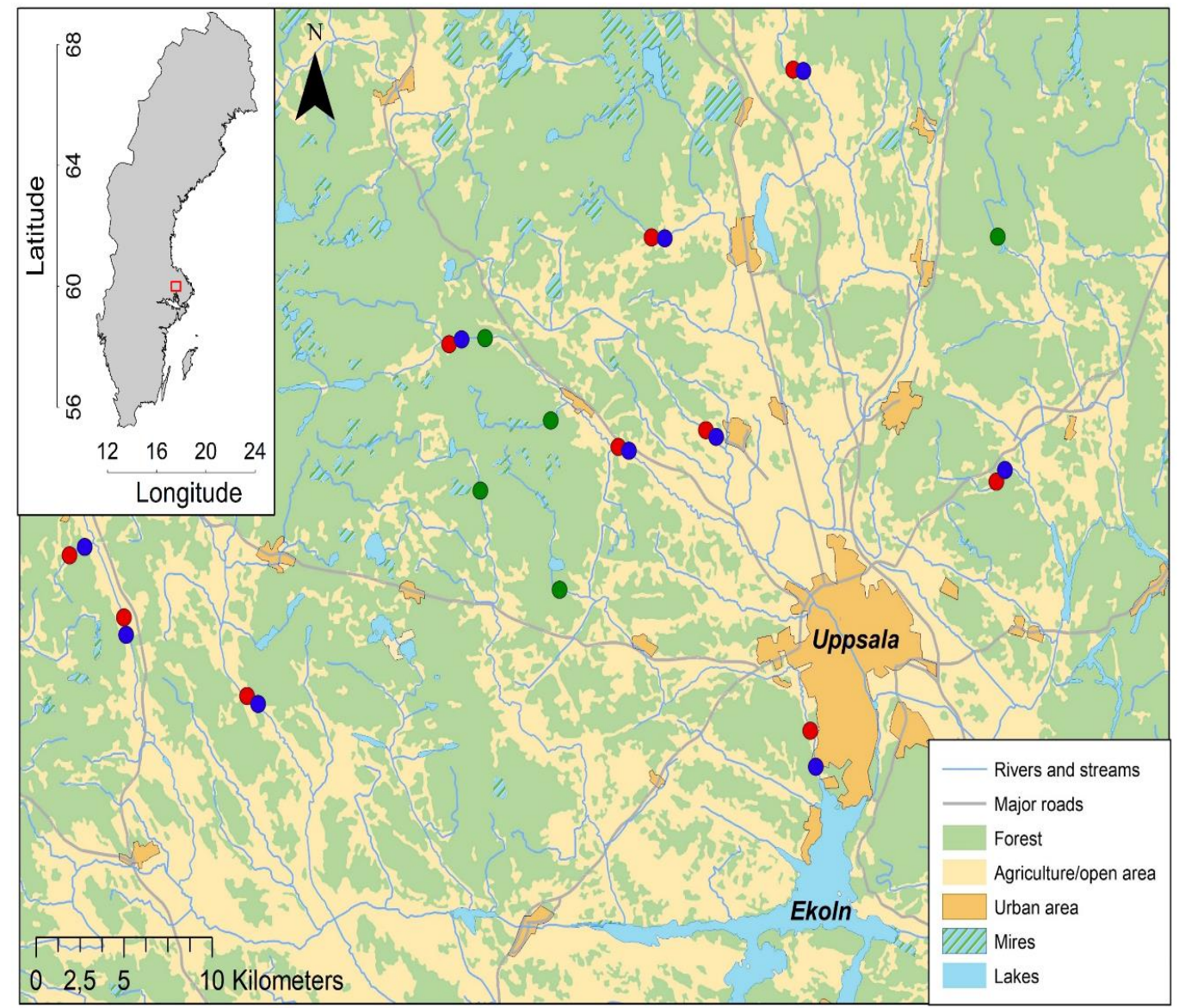

Figure 1. Map of the Ekoln basin with forest sites (green) and paired agricultural sites: (red) unbuffered sites and (blue) buffered sites. Insert map: the red box indicates the study region location in Sweden. 
The study sites consisted of riparian zones along 25 stream reaches in the study catchment. These stream reaches are a subset of the sites described in Burdon et al. [42]. All stream reaches were relatively similar in size (Summer range: width 1-12 m, depth 0.05-0.50 m, Bankfull range: width 2.5-13.5 m, depth $0.30-1.0 \mathrm{~m}$ ) but differed in the extent of riparian wooded vegetation along the banks. Twenty of the reaches comprised 10 paired sites on 10 different streams situated in agricultural areas of the catchment (Figure 1). Each pair consisted of one reach with no or sparse riparian wooded vegetation (henceforth unbuffered) and one reach with riparian wooded vegetation (henceforth buffered). The site pairs were a few hundred meters apart, with the buffered sites downstream from the unbuffered sites. The remaining five sites consisted of reaches flowing through true forest (henceforth forest), which in this study serve to give an increased overview of the types of PUFAs present at the landscape scale.

\subsection{Habitat Assessment}

We assessed riparian habitat and sampled spiders in June-July 2018 following the methods described by Burdon et al. [42]. Site pairs were sampled on the same day, and the time of year meant that temperatures and light conditions were similar at the different times of the day each site was assessed. Overall, sampling was conducted during a period of settled weather characterized by clear skies and warm temperatures. The riparian zone studied consisted of six plots, three on each side of the stream. Each plot measured $10 \mathrm{~m}$ along the stream and $5 \mathrm{~m}$ width from the stream. Three habitat characteristics in each plot were assessed for this study: canopy cover (\%), tree species identification and diversity, and the cover of habitat types (\%). Canopy cover was measured at the centre of each plot using CanopyApp (For Apple iOS, Version 1.0.3, University of New Hampshire, Durham, NH, USA). Trees were identified to species level with the aid of two plant identification applications: British tree identification (For Apple iOS, Version 3.0.1, Woodland Trust, Grantham, UK) and PlantSnap (For Apple iOS, Version 2.01.22, PlantSnap inc., Telluride, CO, USA). The percentage cover of different habitat types (Small trees and shrubs, Herbs (especially taller growing species), Unmanaged grasses, Managed grasses, Mosses and lichens, Rocks and bedrock, Bare ground and Plant litter) were assessed visually for each plot as described in Burdon et al. [42].

\subsection{Riparian Spiders}

Riparian spiders were sampled according to the protocol detailed in Burdon et al. [42], based on a semi-quantitative method involving timed visual searches to obtain a relative indication of abundances. A minimum of four plots were sampled per site (same plots as described above), but in order to obtain enough spiders for fatty-acid analyses 5-6 plots were sampled at some sites. Each plot was searched by $2-3$ people for a standard amount of time (e.g., $10 \mathrm{~min}$ ) and the total area searched within the plot recorded. Plots were sampled methodically along transects parallel to the stream channel to allocate effort evenly. The number of people searching multiplied by the time taken was used to calculate search duration. Sampling duration and area combined with the number of spiders collected (Equation (1)) was used to calculate the catch per unit effort (CPUE). CPUE is a relative measure of abundance, making abundances between sites comparable.

$$
\text { CPUE }=\frac{\text { No. of invertebrates }}{(\text { Total area sampled / Duration of sampling })}
$$

We collected both web-building and free-living spiders from the order Araneae, as well as Harvestmen (Arachnida: Opiliones). Hereafter we refer to both orders together as spiders. Web-building Araneae included Linyphiidae, Araneidae and Tetragnathidae. Two common free-living Araneae were Lycosidae and Pisauridae, and the Opiliones are also free living. We aimed to collect a minimum of 20 individuals per site for each spider group (e.g., free-living and web-building) to meet the required biomass for fatty acid (FA) analyses. We used visual searching to find spiders (i.e., looking for webs, turning over stones and wood and riffling through leaf litter) and guided the 
spiders into labelled sample tubes. The samples were stored on ice and transferred to a freezer $\left(-20^{\circ} \mathrm{C}\right)$ in the laboratory until identification and pre-processing for FA analysis.

\subsection{Invertebrate Identification, Biomass and Fatty Acid Pre-Processing}

We identified individuals while still frozen using a stereo microscope. Spiders (Araneae) were identified to family level using the Araneae key to families [43], and with the aid of Jocqué \& Dippenaar-Sheoman [44] and Kronestedt [45]. Harvestmen (Opiliones) were left at order level, but were almost exclusively members of the sub-order Palapatores. Individuals were later thawed for preparation for FA analyses, including biomass quantification. For each site all spiders belonging to the same family or genus were pooled together to one sample. The pooling was done to average individual variations in FA content, and to reach fatty acids analysis mass requirements $(\approx 5 \mathrm{mg}$ dry weight per sample). The number of individuals per sample was recorded. The samples were freeze-dried (LyoDry compact, Mechatech systems LTD, Bristol, UK) for a minimum of $48 \mathrm{~h}$ at $-45^{\circ} \mathrm{C}$. The samples were then weighed, allowing calculation of biomass CPUE per site based on Equation (1), (with mass replacing number of spiders). The groups targeted for FA analysis (Opiliones, and the Araneae families: Linyphiidae, Tetragnathidae, Lycosidae, and Pisauridae) went through further pre-processing for FA analysis. These target samples were pulverized using a mortar and pestle and then re-weighed to account for loss during grinding. Between each sample the tools used were cleaned with $99 \%$ ethanol to prevent cross-contamination. The samples were then stored in the freezer $\left(-20^{\circ} \mathrm{C}\right)$.

\subsection{Fatty Acid Analysis}

FA analysis was conducted at the Swedish Metabolomics Centre at Umeå University, Sweden, using a method based on Grieve \& Lau [46]. The process included three stages: lipid extraction, methylation, and gas chromatography-mass spectrometry (GC-MS).

Approximately $5 \mathrm{mg}$ (range $4.5-5.5 \mathrm{mg}$ ) of each sample was weighed into labelled micro-centrifuge tubes $(1.5 \mathrm{~mL})$ for FA extraction. Three drops of nano-filtered water were added to re-hydrate the samples. Then $20 \mu \mathrm{L}$ of the internal standard deuterium-labelled pentadecanoic acid $(120 \mathrm{ng} / \mu \mathrm{L})$ and $400 \mu \mathrm{L}$ hexane-isopropanol $(3: 2, V: V)$ extraction solution was added. To homogenize the samples, two metal beads were added to each tube and they were then shaken in a mixer mill (Mixer mill MM 400, Retsch GmbH, Haan, Germany) at 30/s for two minutes. The beads were then removed and $111 \mu \mathrm{L}$ of $6.67 \%$ sodium sulphate solution was added. The samples were vortexed (Vortex Genie 2, Scientific Industries Inc., Bohemia, NY, USA) and left for $30 \mathrm{~min}$ at $4{ }^{\circ} \mathrm{C}$ in darkness. The samples were then centrifuged (Mikro 220R, Hettich $\mathrm{GmbH}$, Tuttlingen, Germany) for five minutes at $18,845 \times \mathrm{g}$ and $4{ }^{\circ} \mathrm{C}$ to separate organics from the aqueous phase. $150 \mu \mathrm{L}$ of the organic phase (supernatant) was extracted and dried with an evaporator at room temperature for two hours under vacuum (miVac Quattro concentrator, Genevac, Ipswich, UK). The dried extract was re-dissolved with $50 \mu \mathrm{L}$ hexane and then $70 \mu \mathrm{L}$ internal standard deuterium-labelled methyl heptadecanoate $(8.57 \mathrm{ng} / \mu \mathrm{L})$ was added, and the samples again vortexed. For each sample, $60 \mu \mathrm{L}$ was methylated and analysed for FA composition.

Prior to methylation the samples were dried with an evaporator using the same parameters described above. To each sample, $200 \mu \mathrm{L}$ of the methylation solution 1:17:83 trimethylsilyldiasomethane:IPA:dichloromethane was then added. The vials were capped and vortexed, then uncapped and left to react and dry for $16 \mathrm{~h}$ at room temperature. The FA methyl esters were then dissolved in $60 \mu \mathrm{L}$ of heptane with the internal standard alkane C13 $(10 \mathrm{ng} / \mu \mathrm{L})$.

The FA methyl esters of the samples were analysed with a GC-MS (7890A GC, Agilent Technologies, Santa Clara, CA, USA \& Pegasus HT TOF-MS, LECO, St. Joseph, MI, USA). The Supelco 37 Component FAME Mix (Sigma-Aldrich Sweden AB, Stockholm, Sweden) and Bacterial Acid Methyl Ester BAME Mix (Sigma-Aldrich Sweden AB, Stockholm, Sweden) were also run to identify the FAs in the samples. The GC-MS was installed with a DB-5 capillary column ( $30 \mathrm{~m}$ length, $250 \mu \mathrm{m}$ internal diameter, $0.25 \mu \mathrm{m}$ film thickness; Agilent Technologies, Santa Clara, CA, USA), and a splitless injection of $1 \mu \mathrm{L}$ was used 
for each sample. The constant flow method was used with helium as the carrier at a rate of $1.0 \mathrm{~mL} / \mathrm{min}$. The inlet temperature was $260{ }^{\circ} \mathrm{C}$ and the oven temperature was set at $70{ }^{\circ} \mathrm{C}$ for $2 \mathrm{~min}$, then increased to $200{ }^{\circ} \mathrm{C}$ at $10^{\circ} \mathrm{C} / \mathrm{min}$, to $270{ }^{\circ} \mathrm{C}$ at $5^{\circ} \mathrm{C} / \mathrm{min}$, and subsequently to $320^{\circ} \mathrm{C}$ at $30{ }^{\circ} \mathrm{C} / \mathrm{min}$, and finally maintained at $320^{\circ} \mathrm{C}$ for $8 \mathrm{~min}$. Concentrations of the individual FAs in each sample were quantified as mg FA per $\mathrm{g}$ dry mass.

\subsection{Data Analysis}

All statistical analyses were conducted using the R statistical computing language and environment, (v. 3.5.2) [47]). Where applicable, data were checked for assumptions of normality and variance with exploratory data analysis (e.g., Q-Q plots) and square-root or natural log transformations applied where necessary. For percentage data, logit or arcsine square-root transformations were applied. Site pairs were not spatially independent, so stream identity was fitted as a blocking factor in all hypothesis testing analyses.

Differences in Shannon diversity, species richness, abundances (CPUE, Equation (1)), and biomass (CPUE) of the spiders between site types were tested with one-way ANOVAs and post-hoc comparisons used Tukey's test to correct for multiple comparisons. Only two families were sufficiently abundant to analyse separately, Linyphiidae and Lycosidae. For these two families differences between site types relating to abundances were examined and the significance tested using ANOVA and post-hoc tests.

To visualize the differences in the community composition of spider families among sites types the data was ordinated using non-metric multidimensional scaling (NMDS) in 2 dimensions. Raw abundance data was Hellinger-transformed to reduce the influence of rare species, an appropriate method ordination based on Euclidean distances [48]. A permutational multivariate analysis of variance (PERMANOVA using the "adonis" function in R [49]) was used to test the difference between site types. Assumptions of homogeneity of spread (i.e., dispersion) were tested using the R functions "betadisper" and "ANOVA" [49].

Habitat assessment data were analysed to determine differences between site types. Redundancy analysis (RDA) was used to examine the variation in spider communities between site types explained by riparian habitat. Habitat variables included tree species classified as coniferous or deciduous to reduce the number of potential explanatory variables. Multicollinearity between habitat variables were checked using pairwise linear correlations and the final model checked using variance inflation factors (VIF), with the VIF limit set to 4. "Moss \& lichen" and "plant litter" had a VIF above 4 and were therefore removed from the analysis [50]. Habitat variables were standardized to a mean of 0 and a standard deviation of 1 . This was achieved using the "decostand" function ("standardize") in the vegan $R$ package which subtracts the mean from each value and divides by the standard deviation. The spider abundance matrix was Hellinger transformed. Model and axis significance were tested using ANOVA (i.e., "anova.cca" in the vegan R package) [49]. In addition, the habitat types in which numerically dominant families (i.e., Linyphiidae and Lycosidae) were collected from were examined separately using barplots.

PUFA concentrations were quantified both in relative terms (i.e., as a proportion of the total FA content), and as concentration in mg PUFA per g dry mass. Principal component analysis (PCA) on log-transformed and standardised PUFA data was used to visually assess patterns in specific PUFAs between site types. A PERMANOVA using the "adonis" function in R [49] tested the difference in the overall PUFA profile between site types, spider families and their interactions. We then constructed univariate models for selected FAs separately, as post-hoc tests to the PERMANOVA to explore which PUFAs varied with site type, spider family and their interaction. These follow-up analyses were conducted using linear mixed-effects (LME) models fitted with the "lmer" function in the lme4 R package [51]. Our LME models used a random intercept term to account for the non-independence of site pairs. We present these to support interpretation of the PERMANOVAS, but emphasise that individual FAs are not independent units and that the univariate models are unable to detect the variation of FA groups in multivariate space. 


\section{Results}

\subsection{Habitat Characterisation of the Site Types}

As expected, site types differed in both composition of tree types and tree densities (Figure S1). Forest sites had the highest tree densities. Buffered sites were mainly dominated by deciduous trees, whereas forest sites had higher densities of conifers. Trunks of dead trees were more common in forest sites (Figure S1). Habitat cover (canopy and types) differed between unbuffered, buffered, and forest sites (Figure S2). Greater canopy cover was observed in buffered and forest sites with an approximate mean of $70 \%$ (Figure S2). Unbuffered sites had substantially lower canopy cover (mean $\approx 40 \%$ ). The herbaceous vegetation layer also varied between site types. In unbuffered sites, the cover of grasses (managed and unmanaged) and herbs was extensive. Buffered sites had relatively high cover of herbs but low cover of grasses, and forest sites had a sparse herbaceous layer (Figure S2). Near-ground habitat types in forest sites were characterised by high cover of moss and lichen, rocks and plant litter. In buffered sites, the cover of plant litter was high, but less moss, lichen and rocks were recorded. In unbuffered sites, the coverage of plant litter, moss and lichen and rock was low. Unbuffered sites had the highest coverage of exposed bare ground.

\subsection{Riparian Spider Diversity and Community Composition}

In total, 1229 spider individuals were collected and identified, belonging to 15 taxa (14 Araneae families and the Opiliones order). Shannon diversity differed between site categories (ANOVA: $F_{2,22}=4.80, p<0.05$ ), with post-hoc testing (Tukey, $p<0.05$ ) indicating the main difference occurred between unbuffered and buffered sites (Figure 2).
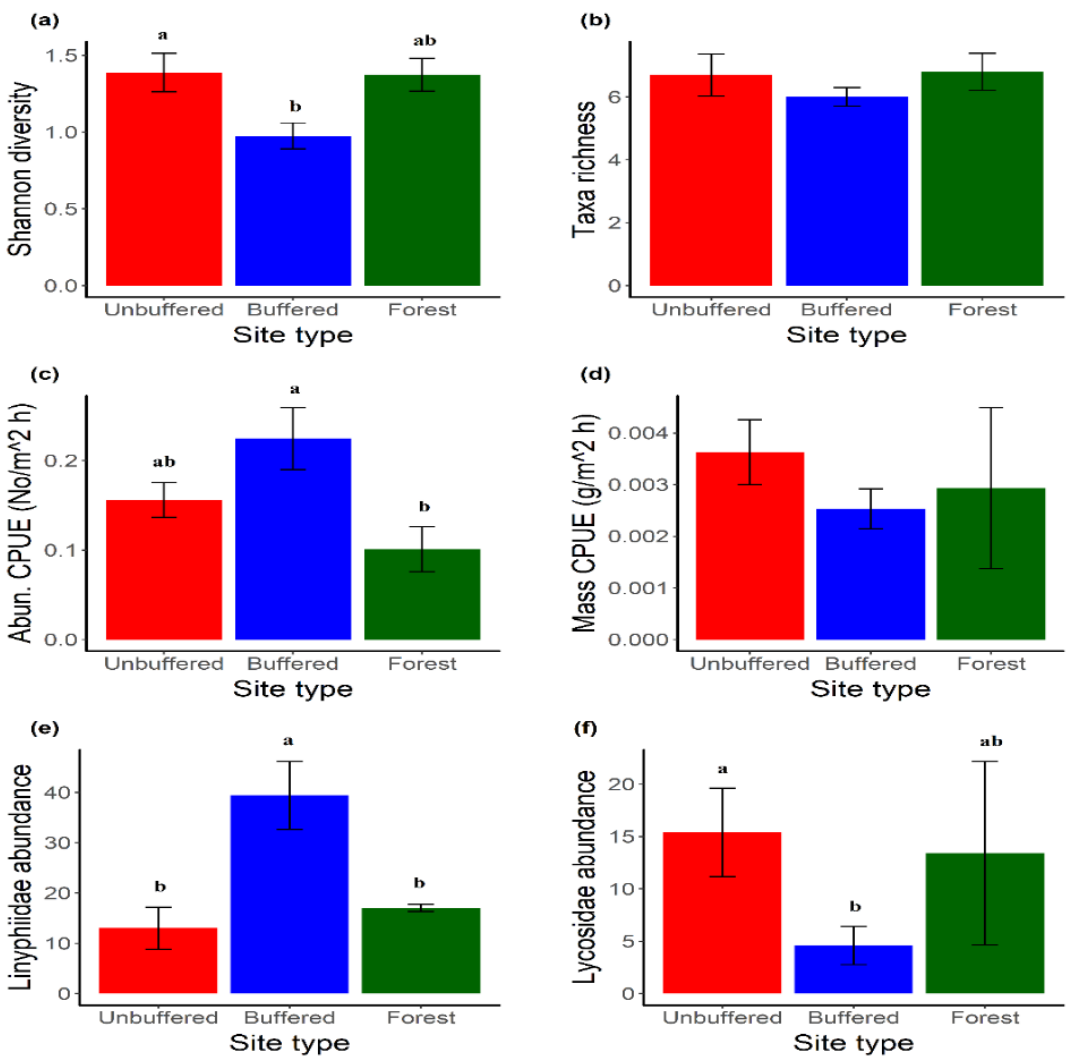

Figure 2. Spider communities: mean \pm SE per site type (Unbuffed, Buffered, Forest) for (a) Shannon diversity, (b) Taxa richness, (c) abundance CPUE (Catch per unit effort), (d) biomass CPUE, (e) Linyphiidae abundance, and (f) Lycosidae abundance. Letters above the bars denote homogenous subsets based on Tukey's post-hoc testing of differences among groups. 
We found no significant differences between site types for taxa richness (Figure 2). Total abundance (CPUE) also differed among site categories (ANOVA: $F_{2,9}=7.84, p<0.01$ ), being highest for buffered sites followed by unbuffered sites and lowest for forest sites (Figure 2). A different pattern was observed for CPUE based on biomass (Figure 2). Unbuffered sites always supported the highest mass per site and hour, though the differences between sites were not significant overall, reflecting an extremely high value for one forest site (Lafsjön).

Linyphiidae (609 individuals) and Lycosidae (267 individuals) were the two most commonly collected families (Table S1). Abundances of Linyphiidae varied significantly between site types (ANOVA: $F_{2,9}=17.22, p<0.001$ ), reflecting much higher abundances at the buffered sites (Figure 2). Lycosidae abundances showed the opposite pattern (Figure 2), with the highest abundances recorded at the unbuffered sites (ANOVA: $F_{2,9}=5.21, p<0.05$ ).

Non-Metric Multidimensional Scaling (NMDS) revealed among-site differences in community composition (Figure 3). Along Axis 1 (NMDS1), the buffered sites on the right side of the plot were mostly associated with web-building spiders such as Linyphiidae and Araneidae, whilst on the left side of the plot unbuffered sites were characterised by Lycosidae, Pisauridae and other free-living families (Figure 3). The forested sites were intermediate between the two groups. PERMANOVA analysis confirmed that spider community composition differed significantly between unbuffered and buffered sites (PERMANOVA: $R^{2}=0.29, F_{1,18}=7.57, p<0.01$ ) but not between the forest sites and unbuffered sites (PERMANOVA: $R^{2}=0.09, F_{1,13}=1.27, p=0.24$ ) or buffered sites (PERMANOVA: $\left.R^{2}=0.11, F_{1,13}=1.58, p=0.18\right)$.

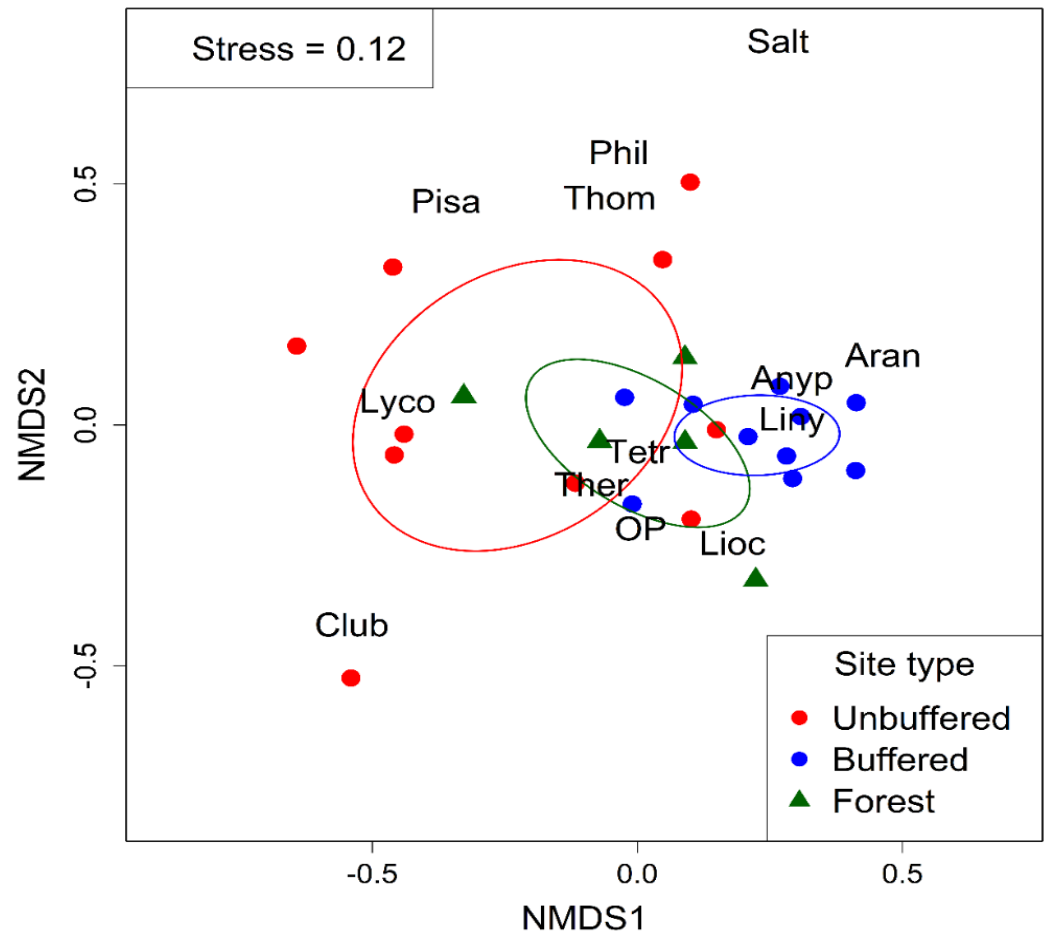

Figure 3. NMDS ordination plot of spider abundances per taxa and site type. Each site is plotted as one point, with points situated closer to one another being more similar in community composition. Association of spider families with the sites is indicated with an overlay of spider family names. Family abbreviations: Anyphaenidae (Anyp); Araneidae (Aran); Clubionidae (Club); Eutichuridae [synonym: Cheiracanthiidae] (Euti); Linyphiidae (Liny); Liocranidae (Lioc); Lycosidae (Lyco); Opiliones (OP); Philodromidae (Phil); Pisauridae (Pisa); Salticidae (Salt); Sparassidae (Spar); Tetragnathidae (Tetr); Theridiidae (Ther); and Thomisidae (Thom). Ellipses represent one standard error of group centroids for individual site types. 


\subsection{Relationships between Habitat and Spider Community Composition}

Differences between spider community composition at the different site types can partly be explained by variation in available habitat (RDA constrained variation $=65.5 \%$ ) (Figure 4 ). The full RDA model was found to be significant (ANOVA: $F_{10,14}=2.66, p<0.01$ ), as was the first axis, RDA 1 (ANOVA: $F_{1,14}=15.48, p<0.001$ ) but not the second (ANOVA: $F_{1,14}=4.61, p=0.12$ ). The first axis (RDA 1), explained $58.2 \%$ of constrained variation. Linyphiidae were most associated with habitat features characteristic of the buffered sites especially, including a higher coverage of tree and shrubs generally, and deciduous trees in particular (Figure 4), and to a lesser degree coverage of herbs (also see Figure S3). Lycosidae were especially associated with managed grass habitats at the unbuffered sites (Figure 4), but also with bare ground and rock in both unbuffered sites and buffered sites, and plant litter and moss and lichen being more common in forest sites (Figure S3). Pisauridae, another free-living spider family, were also associated with habitat features of unbuffered sites, including bare ground and unmanaged grasslands.

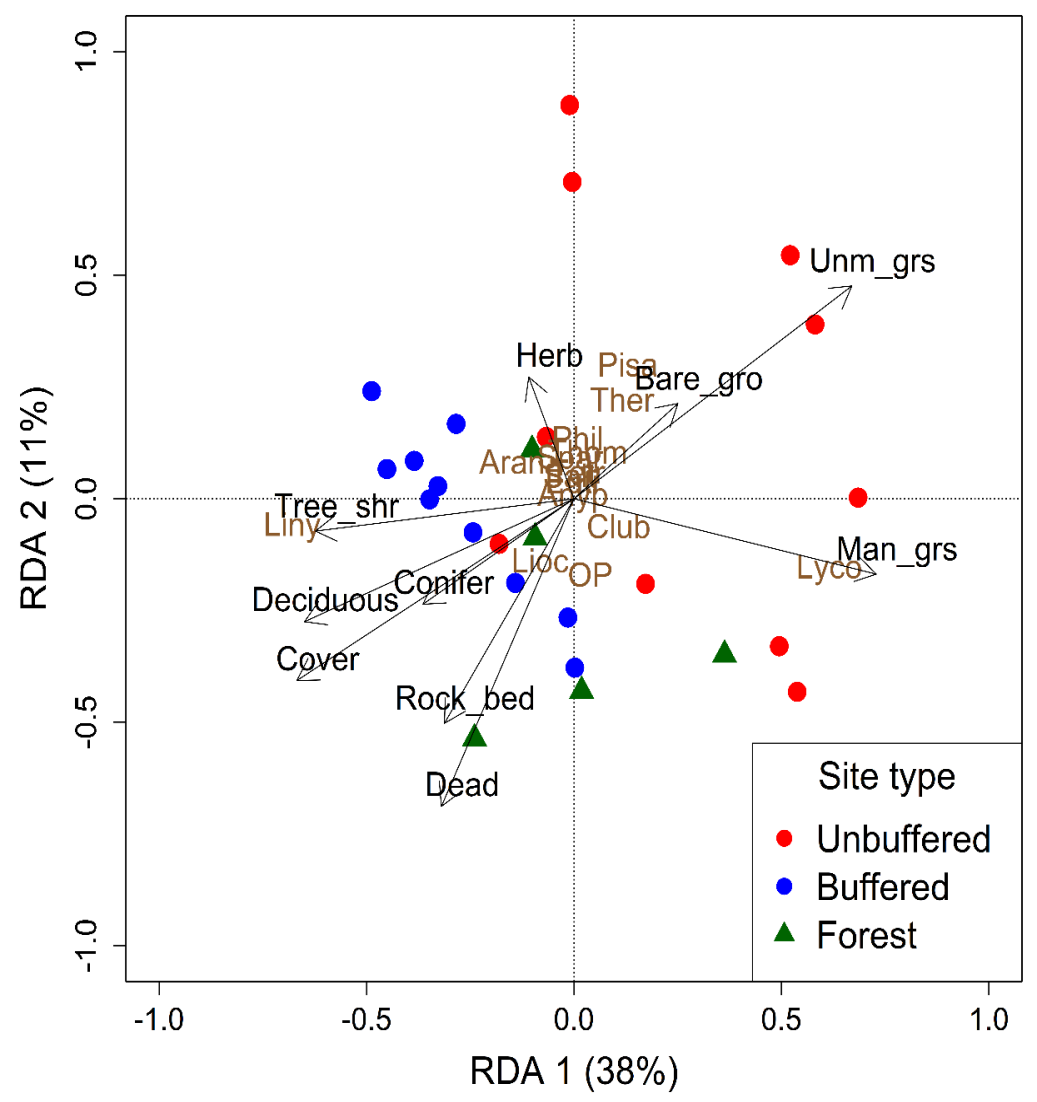

Figure 4. Redundancy analysis (RDA) triplot showing the effect of habitat types on the spider communities. Spider family abbreviations are overlaid in brown text (see Figure 3). Habitat types: Tree_shr, small trees and shrubs; Herb, herbs and forbs; Unm_grs, unmanaged grasses; Man_grs, managed grasses; Rock_bed, rocks and bedrock; Bare_gro, bare ground; cover, canopy cover; Conifer, conifer trees; Deciduous, deciduous trees; and Dead, dead standing wood. Here we used "Scaling 2" in the "rda" $\mathrm{R}$ function: The cosine of angles between all vectors reflect their linear correlations coefficients, e.g., no correlation: $\cos (90)=0$, positive correlation: $\cos (30)=0.87$, strong negative correlation: $\cos (180)=-1$ (Imagined vectors, all lines not drawn to avoid a cluttered plot). Variation explained by the RDA model: $R^{2}=65.5 \%$, Adjusted $R^{2}=40.9 \%$. 


\subsection{General Fatty Acid Profiles of Riparian Spiders}

The target taxa analysed for FA content made up $88.9 \%$ of total spider abundance and $82 \%$ of the total dry mass. Total FA content of the spiders varied between site types (ANOVA: $F_{2,22}=4.45, p<0.05$ ), with forest sites having the highest concentrations and unbuffered sites the lowest FA concentrations, with buffered sites intermediate (Figure 5).

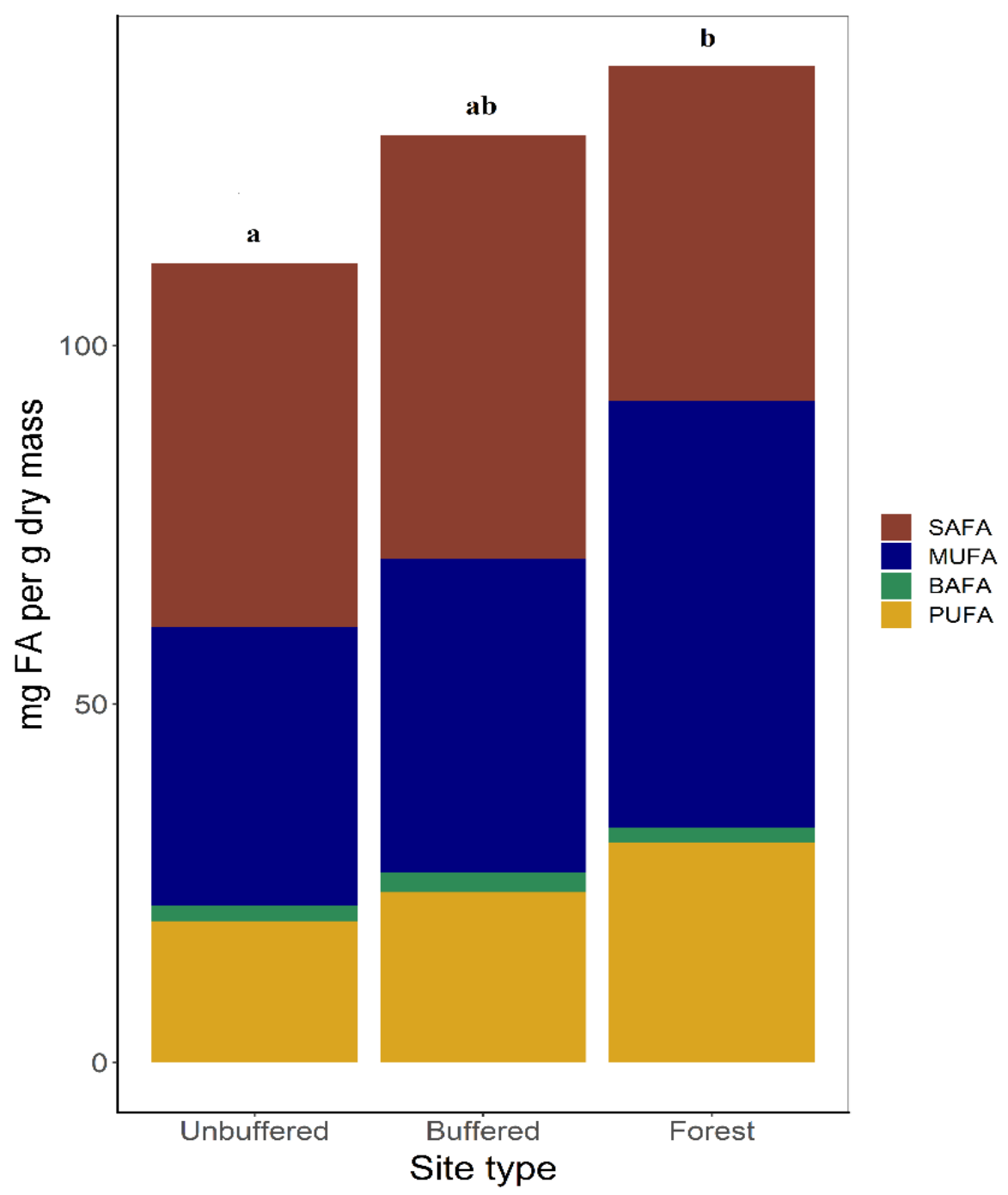

Figure 5. Mean proportion in mg per $g$ dry mass of fatty acids in spiders at the different site types. SAFA: Saturated fatty acids, MUFA: Monounsaturated fatty acids, BAFA: Bacterial fatty acids, PUFA: Polyunsaturated fatty acids. Letters above the bars denote homogenous subsets based on Tukey's post-hoc testing of differences among groups for total FAs.

Similar results were observed for differences in PUFA content between site types (Figure S4, Table 1) both as a percentage of total FA content and as mg PUFA per g dry mass. There were also significant differences in PUFA content among spider families (Table 1, Figure S5). Additionally, the interaction between spider family and site type was significant (Table 1), suggesting that PUFA content of individual spider families changed differently as the riparian vegetation (i.e., site type) changed. 
Table 1. Results of mixed-effects model ANOVAs testing site type, spider family and their interaction on PUFAs (\% of total FA and mg PUFA per $g$ dry mass).

\begin{tabular}{lcccc}
\hline \multicolumn{1}{c}{ Variable } & Num. DF & Den. DF & F-Ratio & $p$-Value \\
\hline PUFA \% of FA & & & & \\
Site type & 2 & 20 & 5.02 & $\mathbf{0 . 0 1}$ \\
Family & 4 & 57 & 4.73 & $\mathbf{0 . 0 0 2}$ \\
Site type $\times$ family & 8 & 57 & 2.51 & $\mathbf{0 . 0 2}$ \\
\hline mg PUFA per g & & & & \\
dry mass & 2 & 16 & 10.43 & $\mathbf{0 . 0 0 1}$ \\
Site type & 4 & 59 & 9.64 & $<\mathbf{0 . 0 0 1}$ \\
Spider family & 8 & 59 & 2.33 & $\mathbf{0 . 0 3}$ \\
Site type $\times$ family & $p$ values highlighted in bold are significant.
\end{tabular}

\subsection{Specific Polyunsaturated Fatty Acids}

In total, eight specific PUFAs were identified: alpha-linolenic acid (ALA 18:3w3), linoleic acid

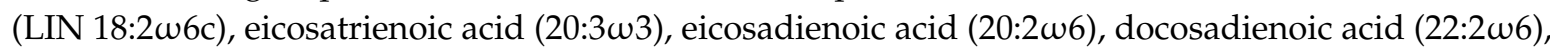

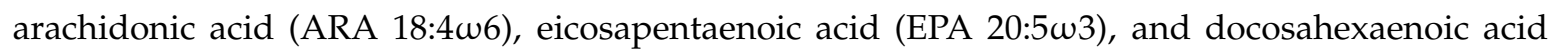
(DHA 22:6w3).

Shifts in the PUFA profiles of spiders among sites were evident in the PCA plot (Figure 6), with unbuffered sites grouped mainly to the bottom right, buffered sites distributed across the middle of the plot, and forest sites clustered predominantly in the top left. DHA, and to a lesser extent ARA and EPA, were associated with stream sites in the agricultural landscape (both unbuffered and buffered sites) in the lower half of the ordination plot. Of these, DHA was most associated with the unbuffered agricultural sites. In contrast, ARA and EPA were more linked with sites towards the left side of PC1 (with negative PC values), crossing the transition from unbuffered through buffered to forested. All remaining PUFAs (e.g., ALA and LIN) were strongly associated with the forested sites to the upper right of the ordination plot.

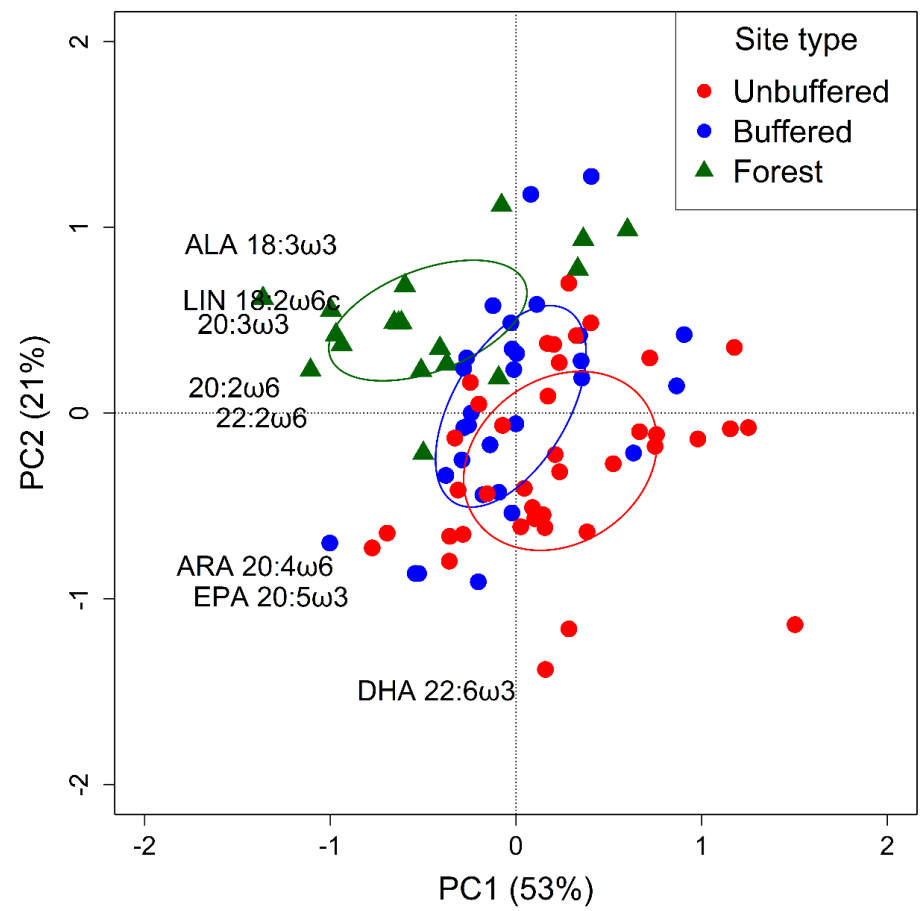

Figure 6. Principal components analysis (PCA) plot describing how spider samples varied in concentrations of eight specific PUFAs by site type. PC1 explains 53.3\% and PC2 explains $20.7 \%$ of the total variance, respectively. The first two PC axes plotted were the only axes with eigenvalues $>1$. 
Specific PUFA content differed between site types (Figure S6, PERMANOVA: $R^{2}=0.10, F_{2,73}=6.87$, $p<0.01$ ), and between spider families (Figure 7, PERMANOVA: $R^{2}=0.24, F_{4,73}=8.09, p<0.001$ ), with an interaction between site type and spider family (Figure S7, PERMANOVA: $R^{2}=0.10, F_{8,73}=1.70$, $p<0.05)$, indicating that spider PUFA composition differed between site types.

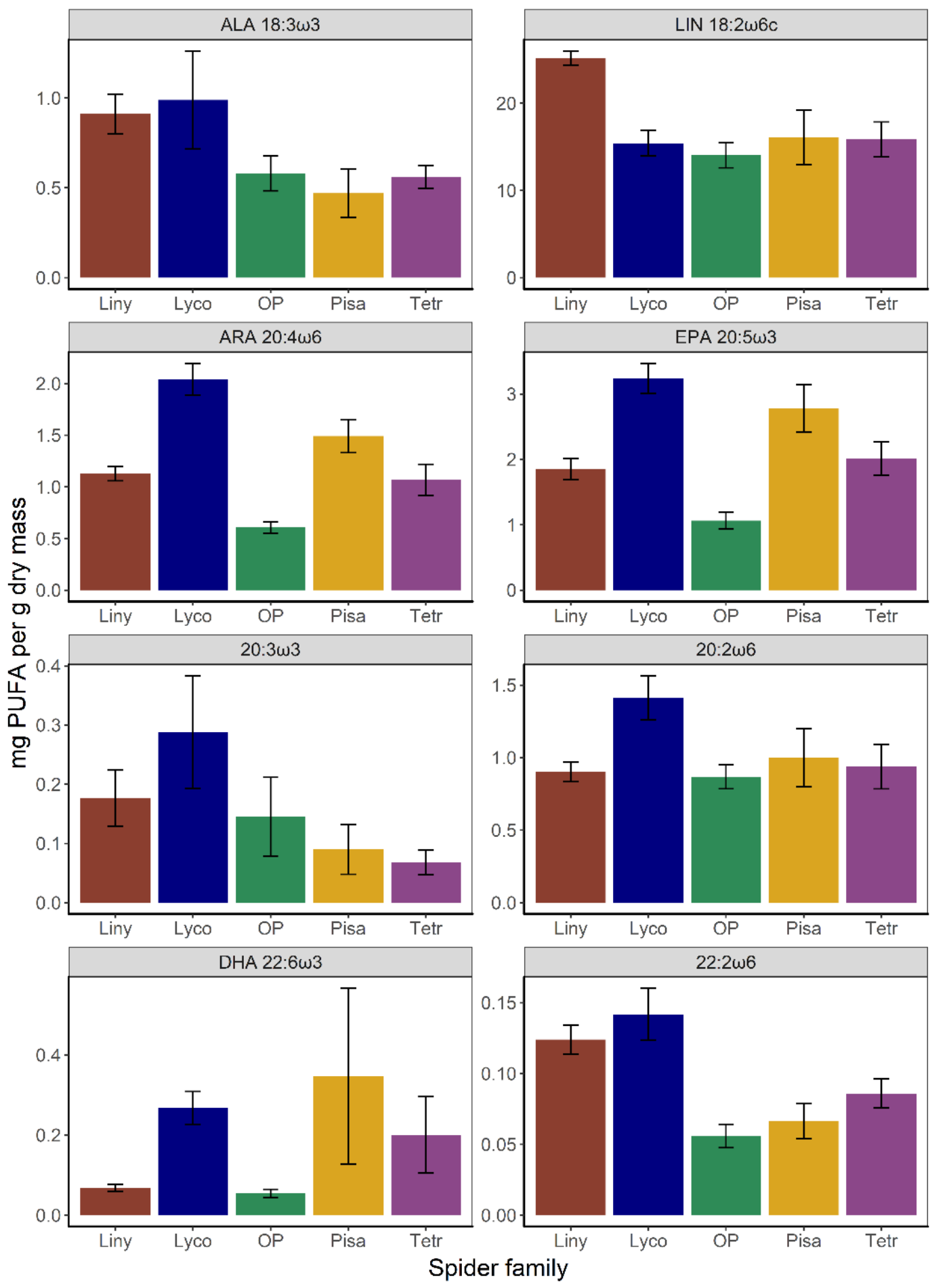

Figure 7. Mean \pm SE PUFA content per spider family of eight specific PUFAs. Spider family abbreviations: Liny, Linyphiidae; Lyco, Lycosidae; OP, Opiliones; Pisa, Pisauridae; Tetr, Tetragnathidae. Please note the different scales on the $y$-axes. 
Analysis for each specific PUFA revealed differences in the influence of site types and spider families (Table 2). For the PUFAs ALA, LIN, eicosatrienoic acid (20:3w3), eicosadienoic acid (20:2w6), docosadienoic acid (22:2w6) significant differences were found in PUFA content between both site types and spider families (Table 2). The content of ARA, EPA and DHA only differed between spider families (Table 2). No interactions between site type and spider family on the individual PUFA level were significant, despite a significant interaction between the two factors at an overall multivariate level.

Table 2. Mixed-effects models ANOVA testing the main effects site type, spider family and their interaction on the content of the eight specific PUFAs.

\begin{tabular}{|c|c|c|c|c|}
\hline Specific & Numerator & Denominator & F-Ratio & $p$-Value \\
\hline PUFA & DF & DF & & \\
\hline \multicolumn{5}{|l|}{ ALA 18:3w3 } \\
\hline Site type & 2 & 37 & 34.51 & $<0.001$ \\
\hline Spider family & 4 & 64 & 7.15 & $<0.001$ \\
\hline Site type $\times$ Spider family & 8 & 63 & 1.99 & 0.06 \\
\hline \multicolumn{5}{|l|}{ LIN 18:2w6c } \\
\hline Site type & 2 & 42 & 6.73 & 0.003 \\
\hline Spider family & 4 & 65 & 5.93 & $<0.001$ \\
\hline Site type $\times$ Spider family & 8 & 64 & 1.83 & 0.09 \\
\hline \multicolumn{5}{|l|}{ ARA 20:4w6 } \\
\hline Site type & 2 & 33 & 1.69 & 0.19 \\
\hline Spider family & 4 & 63 & 21.74 & $<0.001$ \\
\hline Site type $\times$ Spider family & 8 & 62 & 1.25 & 0.29 \\
\hline \multicolumn{5}{|l|}{ EPA 20:5w3 } \\
\hline Site type & 2 & 33 & 1.98 & 0.15 \\
\hline Spider family & 4 & 63 & 19.61 & $<0.001$ \\
\hline Site type $\times$ Spider family & 8 & 63 & 0.85 & 0.56 \\
\hline \multicolumn{5}{|l|}{$20: 3 \omega 3$} \\
\hline Site type & 2 & 31 & 49.54 & $<0.001$ \\
\hline Spider family & 4 & 63 & 22.14 & $<0.001$ \\
\hline Site type $\times$ Spider family & 8 & 62 & 1.59 & 0.14 \\
\hline \multicolumn{5}{|l|}{$20: 2 \omega 6$} \\
\hline Site type & 2 & 40 & 10.66 & $<0.001$ \\
\hline Spider family & 4 & 65 & 4.46 & 0.003 \\
\hline Site type $\times$ Spider family & 8 & 64 & 1.89 & 0.32 \\
\hline \multicolumn{5}{|l|}{ DHA 22:6w3 } \\
\hline Site type & 2 & 48 & 0.79 & 0.46 \\
\hline Spider family & 4 & 65 & 8.10 & $<0.001$ \\
\hline Site type $\times$ Spider family & 8 & 65 & 1.07 & 0.40 \\
\hline \multicolumn{5}{|l|}{$22: 2 \omega 6$} \\
\hline Site type & 2 & 51 & 6.18 & 0.003 \\
\hline Spider family & 4 & 66 & 8.79 & $<0.001$ \\
\hline Site type $\times$ Spider family & 8 & 65 & 1.77 & 0.09 \\
\hline
\end{tabular}

$p$ values highlighted in bold are significant.

Following the PCA analysis (Figure 6), we tested univariate linear models for each FA separately, and found concentrations of ALA, LIN, eicosatrienoic acid (20:3w3), eicosadienoic acid (20:2w6), docosadienoic acid (22:2w6) differed significantly among sites, with all highest in forest sites and lowest in unbuffered sites (Figure S6, Table 2). There was a trend for elevated DHA in the unbuffered sites relative to the forested sites (Figure S6), with buffered sites intermediate, however variability in the unbuffered sites was high and the difference was not statistically significant in the univariate model 
(Table 2). There were no significant differences in concentrations of ARA and EPA among site types (Table 2).

Among spider families, the Lycosidae had the highest content for most of the PUFAs with the exception of LIN and DHA (Table 2, Figure 7). Linyphiidae had the highest LIN content, while DHA was relatively high and even between Lycosidae and Pisauridae, intermediate in Tetragnathidae, and lowest in Opiliones and Linyphiidae (Table 2, Figure 7). The ARA and EPA content of Pisauridae, though lower than Lycosidae, was notably higher than the three other spider families (Figure 7). Opiliones had the lowest PUFA content overall (Figure 7).

Evidence of possible interactions between site type and spider family (PERMANOVA results, see above) on the PUFA content were reflected in the responses of several spider families. Tetragnathidae and Lycosidae from buffered and forest sites showed small increases in EPA concentrations relative to the unbuffered sites (Figure S7). For instance, the median concentrations of EPA in Tetragnathidae from buffered sites was $2.641 \mathrm{mg} / \mathrm{g}(n=6)$, whereas the median was $0.902 \mathrm{mg} / \mathrm{g}(n=7)$ at unbuffered sites; a difference that was statistically significant $\left(X_{1}^{2}=4.14, p<0.05\right)$. However, when the comparison was restricted to cases where Tetragnathidae were found at both the unbuffered and buffered site on the same stream, the increase was more modest and statistically non-significant $\left(X_{1}^{2}=1.71, p=0.191, n=4\right)$. The Lycosidae also showed elevated EPA concentrations at buffered sites, with a median concentration of $3.858 \mathrm{mg} / \mathrm{g}(n=6)$ compared to $2.881 \mathrm{mg} / \mathrm{g}(n=10)$ at unbuffered sites, but this difference was not significant overall and when only stream pairs were compared. For both spider families, concentrations of EPA were elevated at forest sites and more similar to the levels observed at buffered sites. The content of the PUFAs ALA and Eicosatrienoic acid (20:3w3) in Lycosidae found at forest sites was markedly higher in relation to the other families in forest sites, and to Lycosidae at other site types. DHA content of Lycosidae was also high in buffered sites, relative to not only other families at the buffered sites, but also to Lycosidae sampled from forest and unbuffered sites. Forest Pisauridae also had high content of several PUFAs relative to other families and Pisauridae in other site types, however this was based on one individual only (Granlunda forest).

\section{Discussion}

Habitat heterogeneity is generally recognized as a key ecosystem attribute that helps maintain biodiversity, ecosystem functioning and trophic connectivity, but is often highly reduced as a result of human activities $[3,52,53]$. This is particularly true of riparian zones in agricultural landscapes, which, when not under direct cultivation, are often composed of uniform strips of grass or herbs rather than woody vegetation, and are further simplified through reductions in river bank complexity [54-58]. Our results highlight the value of restoring patches of woody riparian "buffer" vegetation in open agricultural landscapes to increase habitat diversity from local to landscape scales, and for the support of biodiversity and trophic connectivity. We found clear differences in riparian spider communities associated with agricultural streams with a woody riparian buffer when compared to those without, and also with the forested sites. This emphasizes the value of a maintaining a mosaic of habitats with lotic riparian zones, to support biodiversity in agricultural landscapes. Additionally, our PUFA biomarkers reveal how the composition and structure of riparian vegetation mediates trophic connections between stream and terrestrial habitats. Woody riparian buffers may enhance resource subsidy quality and trophic connectivity for spider groups such as the Tetragnathidae and Lycosidae, as evidenced by modest increases in EPA content at buffered relative to unbuffered sites [15]. Overall, our findings highlight the complex interplay between riparian habitat structures, the community composition and abundance of terrestrial consumers, and the likely quantity and quality (FAs) of emerging aquatic insects $[21,24,59]$ in mediating aquatic-terrestrial connectivity. 


\subsection{Riparian Spider Communities}

Strong influences of riparian buffer properties on spider communities conform with previous research $[54,55,58]$. As hypothesised, community composition differed between buffered and unbuffered sites. The differences in spider communities between site types were largely shaped by a shift in spider functional types, with web-building spiders (e.g., Linyphiidae) being more common in buffered sites and free-living spiders (e.g., Lycosidae) predominating in unbuffered sites. Several taxa were found almost exclusively at certain site types (e.g., Pisauridae in unbuffered sites). Community composition in the forest sites was intermediate, being similar to buffered sites overall but also including families more typical of unbuffered sites.

Community composition of riparian invertebrates typically varies according to habitat heterogeneity and vegetation structure [38,60-62]. Vegetation provides suitable substrate for web construction, and web-building spider abundances may be limited by available habitat $[22,63]$. In our study, the availability of suitable habitat (trees, shrubs and herbs) in the buffered sites was associated with higher abundances of web-building linyphiid spiders. In contrast, Lycosidae are actively hunting predators relying on visual cues [64], and are thus more adapted to near-ground environments. We found the highest abundances of Lycosidae in sites without a forest buffer on sandbanks and rocks, despite these not being the main groundcover types present. Open areas may allow better access to prey for ground hunting spiders. However, different lycosid species prefer particular habitat types [65-67], and it is possible that we missed more specific species-habitat associations due to our coarse level of taxonomic identification.

Contrary to our hypotheses, spider abundances and biomass (CPUE) did not differ between buffered and unbuffered site pairs. Lower numbers of web-builders at sites without a woody riparian buffer were generally matched by increases in ground-hunting spiders, suggestive of compensatory dynamics in spider communities [68]. Our samples were obtained towards the edges of our stream reaches (i.e., at the downstream end of the unbuffered and unbuffered reaches), and dynamics associated with the meeting of two habitat types might help explain the lack of differentiation between the site pairs. Indeed, a previous meta-analysis [62] found that spider abundances at forest edges were generally high, potentially due to the increased prey availability from two habitats meeting [56,62]. In contrast with the site pairs, spider abundances were relatively low at our forested sites. This suggests that the low productivity of forest streams, documented in previous research [59], results in a more limited supply of adult aquatic insect prey to terrestrial consumers [21]. Although average biomass of terrestrial consumers at forest sites was high overall, this was driven by the abundance of large lycosid individuals at one site (Lafsjön). Overall, differences in spider abundance and biomass between most forest sites and the agricultural sites points towards the interplay of ecosystem productivity and prey availability in concert with habitat structures in regulating spider populations $[6,22,24,37,62,69]$.

Spider taxa diversity was higher in agricultural sites without a forest buffer than buffered sites, contrary to our first hypothesis. However, this result is unlikely to reflect the true influence of woody riparian buffers on biodiversity at the landscape scale. Firstly, we likely missed substantial diversity at the species level. For example, the Linyphiidae dominated the buffered sites numerically, thus reducing diversity at the family level. However, this family are the most speciose in Sweden ( $\approx 300 \mathrm{spp}$. [45]), meaning their numerical dominance was likely to encompass substantial species diversity, undetected in our study. Moreover, much of this additional diversity is likely to be associated with more specialized species. For example, ground-hunting spiders found in forested sites may be more sensitive to habitat loss than those found at the unbuffered sites, reflecting their preference for certain microhabitats provided by the presence of trees and shrubs $[21,55,70]$. Riparian buffers constitute small, isolated patches of forested habitat in a larger, modified landscape, allowing niche refugia for certain species. Assessing the contribution of riparian buffers to terrestrial biodiversity at the landscape scale requires further inventory of highly resolved taxonomic data using the latest molecular tools (e.g., [71]). 


\subsection{Fatty Acid Concentrations and Profiles in Riparian Spiders}

Both total FA and PUFA content of spiders differed between site types, with the highest concentrations found in forest sites and the lowest in unbuffered sites. This result potentially reflects differences in local PUFA production, altered transfer of freshwater PUFAs into terrestrial habitats, and/or differences in spider assemblages and PUFA consumption efficiencies. Greater canopy cover typically favors diatoms that synthesise large quantities of long-chain PUFAs relative to their biomass $[13,30,31,33]$, in addition to enhancing adult aquatic insect dispersal into terrestrial habitats $[9,21]$. These potential benefits of forest cover may facilitate greater PUFA transfer to riparian predators. In this study, we focused on the role of spider taxonomic identity in regulating PUFA transfers to terrestrial food webs.

Overall, we found long-chain PUFA content was highest in spider families that are typically more reliant on aquatic subsidies. Riparian Lycosidae can be highly reliant on aquatic-derived prey [35,38,39], along with wetland specialists Pisauridae [43,72], and web-building Tetragnathidae [35,37]. Moreover, concentrations of several important PUFAs in key taxa rose with increasing forest cover, as supported by the significant interaction between site type and spider family in our PERMANOVA of all FAs combined. For example, concentrations of EPA peaked in Lycosidae and Tetragnathidae from buffered sites. In contrast, DHA concentrations were greater in Pisauridae at the unbuffered sites, albeit with greater variation. These results demonstrate that PUFA content in spiders is driven by environmental and biological contingencies, likely reflecting not only the local availability of PUFAs, but also specific prey-capture traits (e.g., mode, reliance on aquatic prey) and feeding efficiencies.

Organisms in aquatic systems drive most PUFA synthesis, but some specific PUFAs can have different, non-aquatic, sources [32]. Thus, examining differences in specific PUFA profiles is essential for stronger inferences about reliance on aquatic subsidies and aquatic-terrestrial trophic linkages. In our multivariate analysis, two broad groups of PUFAs known to originate almost exclusively in freshwater habitats were apparent. Long-chain PUFAs DHA, EPA, and ARA were associated with agricultural site pairs and are typically produced by algae, and especially diatoms. In contrast, forest sites were associated with FAs produced by bryophytes (including aquatic species) and the flagellate microalgae Raphidophyceae and Euglenophyceae [13,32], including eicosatrienoic acid

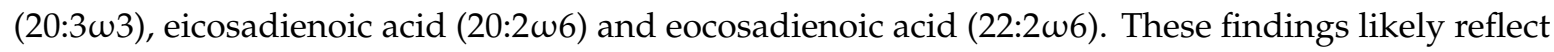
differences in habitat (e.g., shading, water chemistry) driving abundances and production of key aquatic organisms synthesizing PUFAs. We quantified PUFA concentrations in spider tissue, meaning our findings might also reflect differences in PUFA transfer to the riparian zone via emerging aquatic insects, taxa-specific physiological demands for different FAs, and/or spider composition and ability to consume the subsidy $[9,23,24,26,66]$. Importantly, aquatic invertebrates have taxa specific PUFA profiles [32,73], meaning variation in the composition of stream invertebrate cimmunities [74] is also likely to have affected our results.

Algae are major sources of long chain PUFAs DHA, EPA and ARA in freshwater food webs, with diatoms particularly important because they are both palatable for algal grazers and highly efficient at PUFA synthesis [32,33]. Forested stream sections typically favor diatoms, whereas unshaded agricultural streams are generally dominated by green and/or blue-green algae [30,31]. Hence, we expected greater PUFA transfer to terrestrial consumers in our forested site types. We only found some support for this, with EPA peaking modestly in Lycosidae and Tetragnathidae from buffered sites. However, DHA was most associated with unbuffered sites overall. DHA is often a minor fatty acid in diatoms [75], but can be a dominant constituent in dinoflagellates [76] and some species of freshwater Chrysophyceae collectively known as 'golden' algae [77]. Alternatively, shifts in the composition of aquatic algal grazers from emergent insects to invertebrate taxa less available to spiders (e.g., worms and snails) in the buffered sites might offset increases in overall PUFA production by diatoms. However, this is not supported by previous research in the study region, with non-flying taxa more abundant in less shaded streams, which also support high abundances of Chironomidae [21,59]. Rather, our findings most likely reflect strong differences in spider communities of buffered and unbuffered sites. Spiders 
that had high concentrations of these long-chain PUFAs, such as ground-hunting Lycosidae and Pisauridae, along with web-building Tetragnathidae were typically most abundant at the sites without a woody riparian buffer. Habitat properties may have enhanced the ability of these spider group to target aquatic prey. For instance, extensive marginal macrophyte vegetation (e.g., sedges, reeds) at some unbuffered sites likely helped these spiders (e.g., Tetragnathidae) to more effectively capture PUFA-rich aquatic prey.

The FAs typical of forested sites, eicosatrienoic acid, eicosadienoic acid and docosadienoic acid, are all long-chain acids with the first two considered essential PUFAs [78]. Little published information exists on these PUFAs compared to the more commonly studied EPA, DHA and ARA. Eicosatrienoic acid is produced by aquatic bryophytes and freshwater flagellate microalgae (Raphidophyceae) [13,32]. Eicosadienoic acid has been found in another freshwater microalgae flagellate class, Euglenophyceae [13]. No information was found on docosadienoic acid. Our forested sites are heavily shaded and situated on headwater streams, meaning they are small and prone to summer low flows and intermittency [30]. Thus, higher levels of eicosatrienoic acid and eicosadienoic acid in forest may reflect the presence of stream bryophytes and motile flagellate algae adapted to not only shade but also the more marked seasonal fluctuations of these streams [30].

Forest sites were also characterized by the FAs ALA and LIN. These are produced by higher plants, and thus do not necessarily have an aquatic origin. However, Torres-Ruiz et al. [32], found that stream green algae consistently had higher levels of ALA and LIN than allochthonous sources. Further, Arce-Funck et al. [14] found that certain aquatic fungi produced high levels of ALA and LIN. In detrital-based stream food webs typical of forested ecosystems, shading often limits primary production whilst allochthonous inputs are higher [28], meaning fungi could potentially be a major source of these two PUFAs. LIN concentrations in Linyphiidae tended to increase between unbuffered and buffered sites, and were highest overall in the forested sites. This suggests that the presence of forest vegetation was associated with an increased consumption of LIN containing prey by Linyphiidae, which might have been either terrestrial [64], or aquatic [38] in origin.

\subsection{The Transfer of Aquatic PUFAs into Terrestrial Food Webs, and Implications for Management}

Spider PUFA profiles can be used not only to track their dietary preferences and physiological demands, but also the role of spiders in linking aquatic-terrestrial food-webs. Assessment of this role at any given point in space and time requires consideration of (i) variation in abundance and biomass of different spider groups, and (ii) their efficiency in consuming aquatic PUFA-rich prey relative to other types of aquatic prey less rich in these PUFAs. In this study, larger-bodied, ground-hunting spiders (Lycosidae and Pisauridae) appeared to play a significant role in the transport of aquatic-derived PUFAs to terrestrial ecosystems. The combination of high PUFA content with their relatively large size is likely to make them a high-quality resource for higher consumers such as amphibians, birds, and bats that prey upon larger spiders. We found most Lycosidae and Pisauridae in unbuffered sites, and future research might focus on whether this makes these locations attractive for feeding by vertebrate consumers, or whether this is counteracted by certain habitat properties, including the lack of vegetative structures suitable for nests or greater exposure to other predators of these vertebrates [3].

In contrast with ground-hunting lycosids, the aquatic-derived PUFA content of Linyphiidae was more modest. However, this does not necessarily mean that they are unimportant in connecting aquatic and terrestrial food webs. Indeed, their role in facilitating cross-habitat connectivity is likely to be enhanced by woody riparian buffers. Linyphiidae are typically small spiders with webs intercepting insects flying on a vertical plane. The diet of riparian linyphiids is thus likely to encompass not only terrestrial collembolans and aphids [79], but also aquatic-derived dipteran families (e.g., Chironomidae, Simuliidae; [21,59]). These dipterans are generally filter/collector feeders [28] that may be less reliant aquatic algae producing long-chain PUFAs. Thus, although linyphiids might not play a major role in the transfer of high quality aquatic PUFAs, they may still be an important connection between aquatic and terrestrial food-webs. Indeed, the abundances of linyphiids and their web construction points 
to the importance of vegetative habitat along streams for enhancing aquatic-terrestrial connectivity. The addition of riparian buffers in an otherwise open landscape increases the volume of aerial space for web-builders such as linyphiids to intercept both aquatic and terrestrially-derived prey.

\section{Conclusions}

In most agroecosystems, patches of woody vegetation are often rare or non-existent within the riparian zones of streams, rivers and lakes. This is despite the importance of structurally complex and heterogenous vegetation for maintaining biodiversity and ecological linkages [4]. Our results demonstrate that unforested, herbaceous riparian zones and forested buffers play different roles in agricultural catchments, harboring different functional types of spiders in an otherwise impacted landscape. Spider taxonomic identity, which in turn is affected by buffer properties, was the main driver of variations in PUFA content, suggesting that the transfer of aquatic PUFAs from spiders to terrestrial food-webs is mediated through particular families. Woody riparian buffers potentially enhance resource subsidy quality and trophic connectivity for certain groups such as the Tetragnathidae and Lycosidae, as evidenced by modest increases in their EPA content at buffered sites. Additionally, although their aquatic algal PUFA content was comparatively low in relation to riparian specialists such as the Tetragnathidae, linyphiid spiders building webs along stream channels might consume high abundances of emerging insects consuming a higher propotion of allochthonous particulate detritus as aquatic larvae. Accordingly, the high abundances of Linyphiidae at buffered sites is potentially indicative of enhanced trophic connectivity, independent of aquatic PUFA transfer. Overall, inclusion of areas of woody vegetation within a broader riparian habitat matrix [80-82] that also encompasses, for example patches of grassland or exposed rocks, is likely to be an effective land-use mitigation strategy with co-benefits for biodiversity and trophic connectivity in modified landscapes.

Supplementary Materials: The following are available online at http://www.mdpi.com/2073-4441/12/10/2855/s1, Figure S1: Mean number \pm SE (per $300 \mathrm{~m}^{2}$ ) of the tree groups dead, deciduous and conifer found per site type, Figure S2: Mean percent coverage \pm SE (per $300 \mathrm{~m}^{2}$ ) of different habitat types found in unbuffered sites, buffered sites and forest sites. Figure S3: Total number of Linyphiidae and Lycosidae collected in different habitats per site type. Figure S4: Mean PUFA content \pm SE per site type. Figure S5: Mean \pm SE of PUFA content as a percentage of total FA per spider family and site type; Figure S6: Mean \pm SE spider PUFA content per site type of eight specific PUFAs; Figure S7: Mean \pm SE PUFA content per spider family and site type, for eight specific PUFAS; Table S1: Spider family abundances per site and total collected.

Author Contributions: Conceptualization, F.J.B., G.R., R.K.J. and B.G.M.; methodology, all authors; software, E.R.; validation, E.R..; formal analysis, E.R., F.J.B., B.G.M., and D.L.; investigation, E.R., F.J.B. and J.S. resources, F.J.B. and B.K.; data curation, E.R., F.J.B., J.S. and D.C.P.L.; writing-original draft preparation, E.R.; writing-review and editing, all authors; visualization, E.R., F.J.B. and B.G.M. supervision, F.J.B., D.C.P.L. and B.G.M.; project administration, F.J.B., B.K., G.R., and B.G.M.; funding acquisition, B.G.M., R.K.J. and G.R., All authors have read and agreed to the published version of the manuscript.

Funding: This research was conducted as part of the CROSSLINK project funded through the 2015-2016 BiodivERsA COFUND call for research proposals. National funders: the Swedish Research Council for Sustainable Development (FORMAS, projects 2016-01945) and the Swedish Environmental Protection Agency; The Research Council of Norway (NFR, project 264499); The Research Foundation of Flanders (FWO, project G0H6516N), Belgium; the Romanian National Authority for Scientific Research and Innovation (CCCDI-UEFISCDI, project BiodivERsA3-2015-49-CROSSLINK, within PNCDI III); and the Federal Ministry of Education and Research (BMBF, project FKZ: 01LC1621A), Germany. Additional funding was received from the NEXUS project funded by the Swedish Research Council FORMAS (2017-00472).

Acknowledgments: We are grateful to Joel Berglund from the Uppsala County Board who helped identify potential study sites. We thank landowners for access to stream reaches. Daan Van Pul and Erik Gunnars contributed in the field and laboratory.

Conflicts of Interest: The authors declare no conflict of interest. 


\section{References}

1. Biggs, J.; Von Fumetti, S.; Kelly-Quinn, M. The Importance of Small Waterbodies for Biodiversity and Ecosystem Services: Implications for Policy Makers. Hydrobiologia 2017, 793, 3-39. [CrossRef]

2. Keeler, B.L.; Polasky, S.; Brauman, K.A.; Johnson, K.A.; Finlay, J.C.; O’Neill, A.; Kovacs, K.; Dalzell, B. Linking Water Quality and Well-Being for Improved Assessment and Valuation of Ecosystem Services. Proc. Natl. Acad. Sci. USA 2012, 109, 18619-18624. [CrossRef] [PubMed]

3. Naiman, R.J.; Décamps, H. The Ecology of Interfaces: Riparian Zones. Annu. Rev. Ecol. Syst. 1997, 28, 621-658. [CrossRef]

4. Wenger, S. A Review of the Scientific Literature on Riparian Buffer Width, Extent and Vegetation; Institute of Ecology: Athens, GA, USA, 1999.

5. Polis, G.A.; Anderson, W.B.; Holt, R.D. Toward an Integration pf Landscape and Food Web Ecology: The Dynamics of Spatially Subsidized Food Webs. Annu. Rev. Ecol. Syst. 1997, 28, 289-316. [CrossRef]

6. Baxter, C.V.; Fausch, K.D.; Saunders, W.C. Tangled Webs: Reciprocal Flows of Invertebrate Prey Link Streams and Riparian Zones. Freshw. Biol. 2005, 50, 201-220. [CrossRef]

7. Gladyshev, M.; Brett, M.T.; Arts, M.T.; Sushchik, N. Preliminary Estimates of the Export of Omega-3 Highly Unsaturated Fatty Acids (EPA+DHA) from Aquatic to Terrestrial Ecosystems. In Lipids in Aquatic Ecosystems; Springer Science and Business Media LLC: New York, NY, USA, 2009; pp. 179-210.

8. Muehlbauer, J.D.; Collins, S.F.; Doyle, M.W.; Tockner, K. How Wide Is a Stream? Spatial Extent of the Potential "Stream Signature" in Terrestrial Food Webs Using Meta-Analysis. Ecology 2014, 95, 44-55. [CrossRef]

9. Schindler, D.E.; Smits, A.P. Subsidies of Aquatic Resources in Terrestrial Ecosystems. Ecosystems 2017, 20, 78-93. [CrossRef]

10. Bell, M.; Henderson, R.; Sargent, J. The Role of Polyunsaturated Fatty Acids in Fish. Comp. Biochem. Physiol. Part B Comp. Biochem. 1986, 83, 711-719. [CrossRef]

11. Müller-Navarra, D.C.; Brett, M.T.; Liston, A.M.; Goldman, C.R. A Highly Unsaturated Fatty Acid Predicts Carbon Transfer Between Primary Producers and Consumers. Nat. Cell Biol. 2000, 403, 74-77. [CrossRef]

12. Twining, C.W.; Brenna, J.; Hairston, N.G.; Flecker, A.S. Highly Unsaturated Fatty Acids in Nature: What We Know and What We Need to Learn. Oikos 2016, 125, 749-760. [CrossRef]

13. Taipale, S.; Strandberg, U.; Peltomaa, E.; Galloway, A.; Ojala, A.; Brett, M. Fatty Acid Composition as Biomarkers of Freshwater Microalgae: Analysis of 37 Strains of Microalgae in 22 Genera and in Seven Classes. Aquat. Microb. Ecol. 2013, 71, 165-178. [CrossRef]

14. Funck, J.A.; Bec, A.; Perrière, F.; Felten, V.; Danger, M. Aquatic Hyphomycetes: A Potential Source of Polyunsaturated Fatty Acids in Detritus-Based Stream Food Webs. Fungal Ecol. 2015, 13, 205-210. [CrossRef]

15. Chari, L.; Richoux, N.; Moyo, S.; Villet, M. Dietary Fatty Acids of Spiders Reveal Spatial and Temporal Variations in Aquatic-Terrestrial Linkages. Food Webs 2020, 24, e00152. [CrossRef]

16. Richardson, J.S.; Zhang, Y.; Marczak, L.B. Resource Subsidies Across the Land-Freshwater Interface and Responses in Recipient Communities. River Res. Appl. 2009, 26, 55-66. [CrossRef]

17. Allan, J.D. Landscapes and Riverscapes: The Influence of Land Use on Stream Ecosystems. Annu. Rev. Ecol. Evol. Syst. 2004, 35, 257-284. [CrossRef]

18. Corbacho, C.; Sánchez, J.M.; Costillo, E. Patterns of Structural Complexity and Human Disturbance of Riparian Vegetation in Agricultural Landscapes of a Mediterranean Area. Agric. Ecosyst. Environ. 2003, 95, 495-507. [CrossRef]

19. Ollero, A. Channel Adjustments, Floodplain Changes and Riparian Ecosystems of the Middle Ebro River: Assessment and Management. Int. J. Water Resour. Dev. 2007, 23, 73-90. [CrossRef]

20. Renouf, K.; Harding, J.S. Characterising Riparian Buffer Zones of an Agriculturally Modified Landscape. N. Z. J. Mar. Freshw. Res. 2015, 49, 323-332. [CrossRef]

21. Carlson, P.E.; McKie, B.G.; Sandin, L.; Johnson, R.K. Strong Land-Use Effects on the Dispersal Patterns of Adult Stream Insects: Implications for Transfers of Aquatic Subsidies to Terrestrial Consumers. Freshw. Biol. 2016, 61, 848-861. [CrossRef]

22. Laeser, S.R.; Baxter, C.V.; Fausch, K.D. Riparian Vegetation Loss, Stream Channelization, and Web-Weaving Spiders in Northern Japan. Ecol. Res. 2005, 20, 646-651. [CrossRef]

23. Guo, F.; Kainz, M.J.; Sheldon, F.; Bunn, S.E. The Importance of High-Quality Algal Food Sources in Stream Food Webs-Current Status and Future Perspectives. Freshw. Biol. 2016, 61, 815-831. [CrossRef] 
24. Burdon, F.J.; Harding, J.S. The Linkage Between Riparian Predators and Aquatic Insects Across a Stream-Resource Spectrum. Freshw. Biol. 2007, 53, 330-346. [CrossRef]

25. Collier, K.J.; Smith, B.J. Interactions of Adult Stoneflies (Plecoptera) with Riparian Zones I. Effects of Air Temperature and Humidity on Longevity. Aquat. Insects 2000, 22, 275-284. [CrossRef]

26. Hill, W.R.; Ryon, M.G.; Schilling, E.M. Light Limitation in a Stream Ecosystem: Responses by Primary Producers and Consumers. Ecology 1995, 76, 1297-1309. [CrossRef]

27. Stelzer, R.S.; Lamberti, G.A. Effects of N: P Ratio and Total Nutrient Concentration on Stream Periphyton Community Structure, Biomass, and Elemental Composition. Limnol. Oceanogr. 2001, 46, 356-367. [CrossRef]

28. Allan, J.D.; Castillo, M.M.I. Stream Ecology: Structure and Function of Running Waters, 2nd ed.; Springer: Dordrecht, The Netherlands, 2009; ISBN 978-1-4020-5582-9.

29. Larned, S.T. A Prospectus for Periphyton: Recent and Future Ecological Research. J. N. Am. Benthol. Soc. 2010, 29, 182-206. [CrossRef]

30. Richardson, J.S.; Danehy, R.J. A Synthesis of the Ecology of Headwater Streams and their Riparian Zones in Temperate Forests. For. Sci. 2007, 53, 131-147. [CrossRef]

31. Law, R.J. A Review of the Function and Uses of, and Factors Affecting, Stream Phytobenthos. Freshw. Rev. 2011, 4, 135-166. [CrossRef]

32. Torres-Ruiz, M.; Wehr, J.D.; Perrone, A.A. Trophic Relations in a Stream Food Web: Importance of Fatty Acids for Macroinvertebrate Consumers. J. N. Am. Benthol. Soc. 2007, 26, 509-522. [CrossRef]

33. Gladyshev, M.I.; Sushchik, N.N.; Makhutova, O.N. Production of EPA and DHA in Aquatic Ecosystems and Their Transfer to the Land. Prostaglandins Other Lipid Mediat. 2013, 107, 117-126. [CrossRef]

34. Hill, W.R.; Rinchard, J.; Czesny, S. Light, Nutrients and the Fatty Acid Composition of Stream Periphyton. Freshw. Biol. 2011, 56, 1825-1836. [CrossRef]

35. Krell, B.; Röder, N.; Link, M.; Gergs, R.; Entling, M.H.; Schäfer, R.B. Aquatic Prey Subsidies to Riparian Spiders in a Stream with Different Land Use Types. Limnologica 2015, 51, 1-7. [CrossRef]

36. Kato, C.; Iwata, T.; Nakano, S.; Kishi, D. Dynamics of Aquatic Insect Flux Affects Distribution of Riparian Web-Building Spiders. Oikos 2003, 103, 113-120. [CrossRef]

37. Kato, C.; Iwata, T.; Wada, E. Prey Use by Web-Building Spiders: Stable Isotope Analyses of Trophic Flow at a Forest-Stream Ecotone. Ecol. Res. 2004, 19, 633-643. [CrossRef]

38. Stenroth, K.; Polvi, L.E.; Fältström, E.; Jonsson, M. Land-Use Effects on Terrestrial Consumers Through Changed Size Structure of Aquatic Insects. Freshw. Biol. 2014, 60, 136-149. [CrossRef]

39. Paetzold, A.; Schubert, C.J.; Tockner, K. Aquatic Terrestrial Linkages Along a Braided-River: Riparian Arthropods Feeding on Aquatic Insects. Ecosystems 2005, 8, 748-759. [CrossRef]

40. Uppsala Kommun. Statistik om Uppsala Kommun 2018; Analysenheten: Uppsala, Sweeden, 2018.

41. SMHI Månads-, årstids- och årskartor. Available online: https://www.smhi.se/klimatdata/meteorologi/kartor/ monYrTable.php?par=tmpAvv (accessed on 15 April 2019).

42. Burdon, F.J.; Ramberg, E.; Sargac, J.; Forio, M.A.E.; De Saeyer, N.; Mutinová, P.T.; Moe, T.F.; Pavelescu, M.O.; Dinu, V.; Cazacu, C.; et al. Assessing the Benefits of Forested Riparian Zones: A Qualitative Index of Riparian Integrity Is Positively Associated with Ecological Status in European Streams. Water 2020, 12, 1178. [CrossRef]

43. Nentwig, W.; Blick, T.; Gloor, D.; Hänggi, A.; Kropf, C. Spiders of Europe, Version (9) 2018. Available online: https://araneae.nmbe.ch (accessed on 15 September 2018).

44. Jocqué, R.; Dippenaar-Schoeman, A.S. Musée Royal de l'Afrique Centrale. In Spider Families of the World, 2nd ed.; Musée Royal de l'Afrique Centrale: Tervuren, Belgium, 2007; ISBN 978-90-74752-11-4.

45. Kronestedt, T. Checklist of Swedish Spiders in Sweden. Available online: http://www2.nrm.se/en/svenska spindlar/spindlar.html (accessed on 15 April 2019).

46. Grieve, A.; Lau, D.C.P. Do Autochthonous Resources Enhance Trophic Transfer of Allochthonous Organic Matter to Aquatic Consumers, or Vice Versa? Ecosphere 2018, 9, e02307. [CrossRef]

47. R Core Team. R: A Language and Environment for Statistical Computing; R Foundation for Statistical Computing: Vienna, Austria, 2018.

48. Legendre, P.; Gallagher, E.D. Ecologically Meaningful Transformations for Ordination of Species Data. Oecologia 2001, 129, 271-280. [CrossRef] 
49. Oksanen, J.; Blanchet, F.G.; Friendly, M.; Kindt, R.; Legendre, P.; McGlinn, D.; Minchin, P.R.; O’Hara, R.B.; Simpson, G.L.; Solymos, P.; et al. Vegan: Community Ecology Package; Comprehensive R Archive Network: Berkely, CA, USA, 2019.

50. Quinn, G.; Keough, M. Experimental Design and Data Analysis for Biologists, 1st ed.; Cambridge University Press: Cambridge, UK, 2002.

51. Bates, D.; Mächler, M.; Bolker, B.; Walker, S. Fitting Linear Mixed-Effects Models Using lme4. J. Stat. Softw. 2015, 67, 1-48. [CrossRef]

52. Frainer, A.; Polvi, L.E.; Jansson, R.; McKie, B.G. Enhanced Ecosystem Functioning Following Stream Restoration: The Roles of Habitat Heterogeneity and Invertebrate Species Traits. J. Appl. Ecol. 2017, 55, 377-385. [CrossRef]

53. Hasselquist, E.M.; Polvi, L.E.; Kahlert, M.; Nilsson, C.; Sandberg, L.; McKie, B.G. Contrasting Responses among Aquatic Organism Groups to Changes in Geomorphic Complexity Along a Gradient of Stream Habitat Restoration: Implications for Restoration Planning and Assessment. Water 2018, 10, 1465. [CrossRef]

54. Schultz, R.C.; Isenhart, T.M.; Simpkins, W.W.; Colletti, J.P. Riparian Forest Buffers in Agroecosystems-Lessons Learned from the Bear Creek Watershed, Central Iowa, USA. Agrofor. Syst. 2004, 61, 35-50.

55. Naiman, R.J.; Décamps, H.; McClain, M.E. Riparia: Ecology, Conservation, and Management of Streamside Communities; Elsevier Science \& Technology: Burlington, VT, USA, 2005; ISBN 978-0-08-047068-9.

56. Clark, W.R.; Reeder, K.F. Agricultural Buffers and Wildlife Conservation: A Summary About Linear Practices. In Fish and Wildlife Response to Farmland Conservation Practices; The Wildlife Society: Bethesda, MD, USA, 2007; pp. 45-55.

57. Degerman, E.; Bergqvist, B. Ekologiskt Funktionella Kantzoner. In Ekologisk Restaurering av Vattendrag; Degerman, E., Ed.; Naturvårdsverket och Fiskerieverket: Göteborg, Stockholm, 2008; pp. 33-52.

58. Bjelke, U.; Boberg, J.; Oliva, J.; Tattersdill, K.; McKie, B.G. Dieback of Riparian Alder Caused by Thephytophthora Alnicomplex: Projected Consequences for Stream Ecosystems. Freshw. Biol. 2016, 61, 565-579. [CrossRef]

59. McKie, B.G.; Sandin, L.; Carlson, P.E.; Johnson, R.K. Species Traits Reveal Effects of Land Use, Season and Habitat on the Potential Subsidy of Stream Invertebrates to Terrestrial Food Webs. Aquat. Sci. 2018, 80, 15. [CrossRef]

60. Perner, J.; Malt, S. Assessment of Changing Agricultural Land Use: Response of Vegetation, Ground-Dwelling Spiders and Beetles to the Conversion of Arable Land into Grassland. Agric. Ecosyst. Environ. 2003, 98, 169-181. [CrossRef]

61. Batáry, P.; Baldi, A.; Samu, F.; Szúts, T.; Erdős, S. Are Spiders Reacting to Local or Landscape Scale Effects in Hungarian Pastures? Biol. Conserv. 2008, 141, 2062-2070. [CrossRef]

62. Prieto-Benítez, S.; Méndez, M. Effects of Land Management on the Abundance and Richness of Spiders: A Meta-Analysis. Biol. Conserv. 2011, 144, 683-691. [CrossRef]

63. Chan, E.K.W.; Zhang, Y.; Dudgeon, D. Substrate Availability May Be More Important than Aquatic Insect Abundance in the Distribution of Riparian Orb-web Spiders in the Tropics. Biotropica 2009, 41, 196-201. [CrossRef]

64. Nyffeler, M. Prey Selection of Spiders in the Field. J. Arachnol. 1999, 27, 317-324.

65. Moring, J.B.; Stewart, K.W. Habitat Partitioning by the Wolf Spider Guild in Streamside and Riparian Vegetation Zones of the Conejos River, Colorado. J. Arachnol. 1994, 22, 205-217.

66. Lambeets, K.; Hendrickx, F.; Vanacker, S.; Van Looy, K.; Maelfait, J.-P.; Bonte, D. Assemblage Structure and Conservation Value of Spiders and Carabid Beetles from Restored Lowland River Banks. Biodivers. Conserv. 2008, 17, 3133-3148. [CrossRef]

67. Artdatabanken, SLU Artfakta spindlar. Available online: https://artfakta.artdatabanken.se (accessed on 21 April 2019).

68. Supp, S.R.; Ernest, S.K.M. Species-Level and Community-Level Responses to Disturbance: A Cross-Community Analysis. Ecology 2014, 95, 1717-1723. [CrossRef] [PubMed]

69. Burdon, F.J. Agriculture and Mining Contamination Contribute to a Productivity Gradient Driving Cross-Ecosystem Associations between Stream Insects and Riparian Arachnids. In Contaminants and Ecological Subsidies: The Land-Water Interface, 1st ed.; Kraus, J.M., Walters D., M., Mills, M.A., Eds.; Springer: New York, NY, USA, 2020; 384p. 
70. Moore, R.D.; Spittlehouse, D.L.; Story, A. Riparian Microclimate and Stream Temperature Response to Forest Harvesting: A Review. J. Am. Water Resour. Assoc. 2005, 41, 813-834. [CrossRef]

71. Karlsson, D.; Hartop, E.A.; Forshage, M.; Jaschhof, M.; Ronquist, F. The Swedish Malaise Trap Project: A 15 Year Retrospective on a Countrywide Insect Inventory. Biodivers. Data J. 2020, 8, e47255. [CrossRef] [PubMed]

72. Duffey, E. The Distribution, Status and Habitats of Dolomedes Fimbriatus (Clerck) and D. Plantarius (Clerck) in Europe; Ruzicka, V., Ed.; Institute of Entomology: Ceske Budejovice, Czech Republic, 1995; pp. 54-65.

73. Lau, D.C.P.; Vrede, T.; Pickova, J.; Goedkoop, W. Fatty Acid Composition of Consumers in Boreal Lakes-Variation Across Species, Space and Time. Freshw. Biol. 2011, 57, 24-38. [CrossRef]

74. Carlson, P.E.; Johnson, R.K.; McKie, B.G. Optimizing Stream Bioassessment: Habitat, Season, and the Impacts of Land Use on Benthic Macroinvertebrates. Hydrobiologia 2012, 704, 363-373. [CrossRef]

75. Napolitano, G.E. The Relationship of Lipids with Light and Chlorophyll Measurements in Freshwater Algae and Periphyton1. J. Phycol. 1994, 30, 943-950. [CrossRef]

76. Scholz, B.; Liebezeit, G. Biochemical Characterisation and Fatty Acid Profiles of 25 Benthic Marine Diatoms Isolated From the Solthörn Tidal Flat (Southern North Sea). J. Appl. Phycol. 2013, 25, 453-465. [CrossRef]

77. Ahlgren, G.; Gustafsson, I.-B.; Boberg, M. Fatty Acid Content and Chemical Composition of Freshwater Microalgae. J. Phycol. 1992, 28, 37-50. [CrossRef]

78. Cunnane, S. The Conditional Nature of the Dietary Need for Polyunsaturates: A Proposal to Reclassify 'Essential Fatty Acids' as ‘Conditionally-Indispensable' or 'Conditionally-Dispensable' Fatty Acids. Br. J. Nutr. 2000, 84, 803-812. [CrossRef] [PubMed]

79. Sunderland, K.D.; Fraser, A.M.; Dixon, A.F.G. Field and Laboratory Studies on Money Spiders (Linyphiidae) as Predators of Cereal Aphids. J. Appl. Ecol. 1986, 23, 433. [CrossRef]

80. Riis, T.; Kelly-Quinn, M.; Aguiar, F.C.; Manolaki, P.; Bruno, D.; Bejarano, M.D.; Clerici, N.; Fernandes, M.R.; Franco, J.C.; Pettit, N.; et al. Global Overview of Ecosystem Services Provided by Riparian Vegetation. BioScience 2020, 70, 501-514. [CrossRef]

81. Samways, M.J.; Barton, P.S.; Birkhofer, K.; Chichorro, F.; Deacon, C.; Fartmann, T.; Fukushima, C.S.; Gaigher, R.; Margules, C.; Hallmann, C.A.; et al. Solutions for Humanity on How to Conserve Insects. Biol. Conserv. 2020, 242, 108427. [CrossRef]

82. Mutinova, P.T.; Kahlert, M.; Kupilas, B.; McKie, B.G.; Friberg, N.; Burdon, F.J. Benthic Diatom Communities in Urban Streams and the Role of Riparian Buffers. Water 2020, 12, 2799.

Publisher's Note: MDPI stays neutral with regard to jurisdictional claims in published maps and institutional affiliations.

(C) 2020 by the authors. Licensee MDPI, Basel, Switzerland. This article is an open access article distributed under the terms and conditions of the Creative Commons Attribution (CC BY) license (http://creativecommons.org/licenses/by/4.0/). 